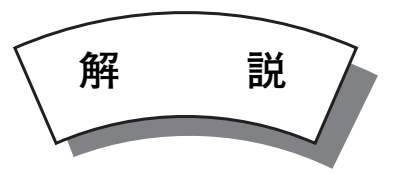

\title{
金属材料の相転移物性と格子歪エネルギー
}

\section{Correlation Between Phase Transition Properties and Lattice-strain Energetics in Metallic Materials}

森口晃治* ・五十嵐正 晃**

Koji MORIGUCHI and Masaaki IGARASHI

Key Words: Phase Transition, Friedel Model, Bain Path, Lattice-strain Energetics, Dynamical Instability

\section{1. はじめに}

相転移温度は、着目相の相安定性を測る定量指標となる ため、工業的な材料やプロセス開発には最も重要な物性值 の一つである。例えば、凝固現象において重要な物性值と なる融点は、工業的な固体材料においても高温耐性を定性 的に表す重要な指標としてしばしば利用されている。

代表的な一次相転移となる融解現象 (固液相転移) では、 “固体の融解の本質とはいかなるものか“という基本的な 問題が現在でも存在する。この問題に対して、融解前の固 体相に着目し、固体物性論の立場から融解現象の本質に迫 ろうという思想は古く、前世紀初頭の Lindemann ${ }^{1)} や$ Born $^{2)}$ の仕事に遡る。彼らは、それぞれ、Lindemann criterionあ るいは Born criterion と今日呼ばれる、「相転移は連続反応 (successive reactions)である」とする Ostwald の Step Rule 的 基準概念を ${ }^{3)}$ 、固液相転移に対し提案した。前者は、固体 における原子振動の振幅がある閾值に達することが融解現 象につながるとするもの ${ }^{1)}$ 、後者は、融解現象には固体の 弾性物性が関与し剛性率 (shear modulus) あるいはその異方 性がゼロとなる点が融点であるとするものである ${ }^{2)} 。$ 相転 移前の相の状態の energetics（あるいは instability）と相転 移物性の相関を捉えようとするこのような思想は、ミクロ 理論からの直接的導出が難しい転移温度のような物理量を あからさまに求めることなく、材料のトレンドを把握する 指導原理のようなものにもなり得るため、材料設計という 観点からも有用となる。

本稿では、結晶固体が持つ弾性物性が、熱力学相安定性 に関する物性と、ミクロ的観点からはどのようにつながる

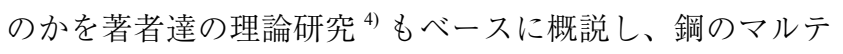
ンサイト変態過程の弾性物性その場測定実験の研究報告に 橋渡ししたい。

\section{2. 遷移金属における Friedel モデル}

本節では、遷移金属系の凝集物性の周期律表のトレンド を概観するのに有用な Friedel モデル 5) を紹介する。

遷移金属の凝集力や原子間結合に関わる物性は、合金系 も含め考察対象系の原子 1 個当たりの $\mathrm{d}$ 電子数 $\left(n_{d}\right)$ で整理 できることが多い。その一例として、結晶の融点と $\mathrm{d}$ 電子 数の関係を Fig. 1 に示す。 $3 \mathrm{~d}$ 遷移金属系では磁性に由来す る例外もあるものの、概ね $\mathrm{d}$ 電子数が $n_{d}=5$ 程度で融点が 高くなる放物線的な振る舞いを示すことが分かる。この挙 動に対するシンプルで明快な物理を与えたものが Friedel モ デルとなる。

Friedel モデルでは、遷移金属に対して Fig. 2(a)に示す矩

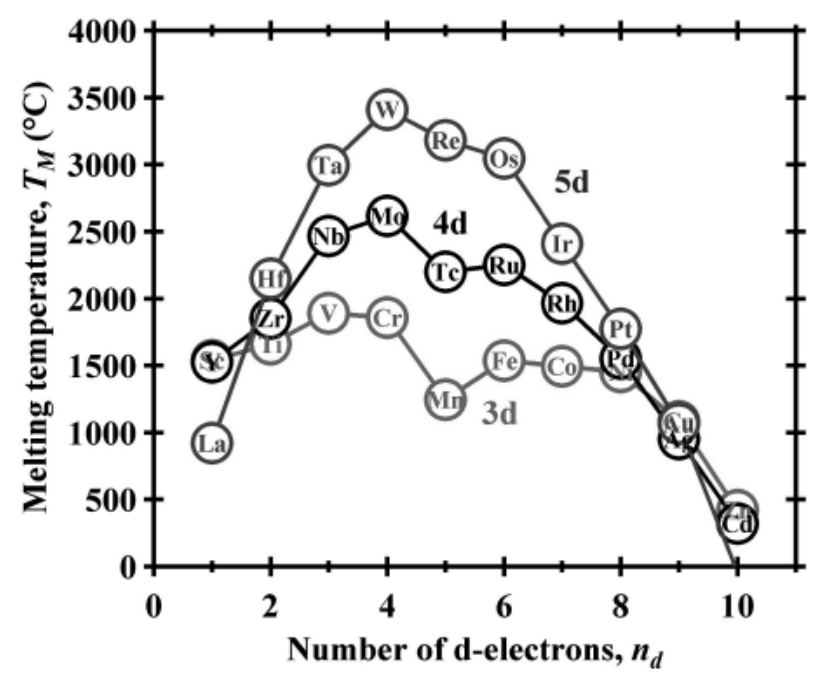

Fig. 1 Melting temperatures ${ }^{6)}$ as a function of number of d-electrons $\left(n_{d}\right)$ for transition metal series.

\footnotetext{
* 新日鉄住金(株) 技術開発本部 鉄鋼研究所（广 660-0891 兵庫県尼崎市扶桑町 1-8）

Steel Research Laboratories, Technical Research \& Development Bureau, Nippon Steel and Sumitomo Metal Corporation (1-8 Fuso-cho, Amagasaki, Hyogo, 660-0891 Japan)

***新日鐵住金(侏) 技術開発本部 フェロー（～660-0891 兵庫県尼崎市扶桑町 1-8）

Technical Research \& Development Bureau, Nippon Steel and Sumitomo Metal Corporation (1-8 Fuso-cho, Amagasaki, Hyogo, 660-0891 Japan)
} 


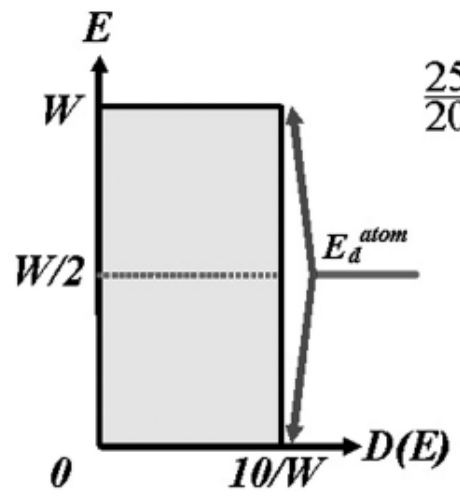

(a)

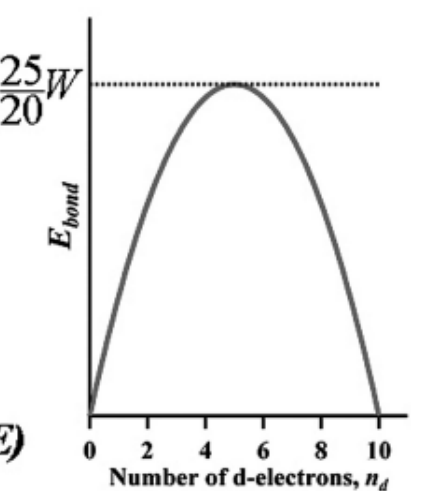

(b)
Fig. 2 Friedel Model. (a) Rectangular DOS and (b) Bond energy $\left(E_{\text {bond }}\right)$ as a function of $n_{d}$.

形の電子状態密度 (Density of States: DOS) を仮定し系の凝 集機構を考察する。ここで、孤立原子状態で縮退している $5 つ の \mathrm{~d}$ 軌道準位 $\left(E_{d}^{\text {atom }}=\mathrm{W} / 2\right)$ が、結晶固体のような凝縮 系の形成で、バンド幅 $\mathrm{W}$ を持つ電子バンドに分裂したとす る。スピン分極を考慮しなければ $5 つ の \mathrm{~d}$ 軌道準位には 10 個の電子を占有させることが可能なので、矩形モデルを利 用する Friedel モデルにおけるDOS の高さ $D(E)=10 / W$ と なる。この時、系の電子数 $n_{d}$ とフェルミレベル $E_{F}$ は、

$$
n_{d}=\int_{0}^{E_{F}} D(E) d E=\frac{10}{W} E_{F}
$$

の関係で結ばれる。凝縮系の形成による孤立原子状態から の全エネルギーの利得を $E_{c o h}$ とすれば、

$$
\begin{aligned}
E_{c o h} & \equiv \int_{0}^{E_{F}} D(E) E d E-n_{d} E_{d}^{\text {atom }} \\
& =-\frac{W}{20} n_{d}\left(10-n_{d}\right) \equiv-E_{b o n d} \\
& \left(\because D(E)=\frac{10}{W}, E_{F}=\frac{W}{10} n_{d}\right)
\end{aligned}
$$

と書かれる。 $E_{c o h}$ の負值で定義した $E_{b o n d}$ が凝集エネルギー であり、系の原子間結合強さの指標となる。Friedel モデル の重要な帰結は、“遷移金属合金系では凝集力や原子間結合 に関わる物性は、 d バンドへの電子占有数が本質的に決め てしまう”ということである。

Fig. 2(b)に $E_{\text {bond }}$ と $n_{d}$ との関係を示す。系の原子間結合は、 $\mathrm{d}$ 電子の数が 5 個の場合に最も強く、さらにバンド分裂幅 $W$ が大きいほど $E_{\text {bond }}$ の最大值が大きくなることが分かる。 $n_{d}<5$ の d バンド状態が結合準位 (bonding state) に相当する 電子バンドであり、この領域では電子占有に伴って原子間 結合力が増大するが、 $n_{d}>5$ では反結合準位 (anti-bonding state)への電子占有となるため結合力が減少すると、電子論 的には説明される。また、遷移金属系では周期律表の下側
にいくにつれ、実際のバンド幅も増大することが良く知ら れている7)。Fig. 1 において、タングステン（W 元素）が、 何故、融点が高いのかは、このシンプルな Friedel モデルか ら明瞭に説明される訳である。

Friedel モデルは、上述のバルク凝集物性だけでなく、表 面エネルギーや化学反応性の考察にも有用である。遷移金 属合金系では、フェルミレベル近傍の電子状態が局在性の 強い $\mathrm{d}$ バンドから成るため、構成原子間には“ボンドの形 成”という概念が成立する。バルク状態で強い原子間結合 を有する $n_{d}=5$ 付近の元素系では、その表面では強いボン ドが途切れる原子（ダングリングボンド）が存在するため、 化学的に活性となり表面エネルギーが高くなる。したがっ て、表面エネルギーの周期律表推移についても、Fig. 2(b) と同様な $n_{d}$ に対して放物線的振る舞いとなることが予想さ れる。実際に、第一原理計算よっても、Friedel モデルから 予測される Fig. 2(b) に示すような表面エネルギーの周期律 表推移が観測されている ${ }^{8)}$ 。遷移金属合金では、高強度（原 子間結合力の増大）と耐食特性（耐表面化学反応性）の両 立が難しいという物理的な根拠である。

鋼や $\mathrm{Ni}$ 基合金のような合金系は、母相の $\mathrm{d}$ 電子数が $n_{d}>$ 5 の合金系であるため、 $\mathrm{d}$ バンドの電子占有数を増加させる 元素（電子ドナー元素：鉄鋼材料では耐食性元素と称され る）には、表面エネルギーを下げる局所駆動力が働き、か なり強い表面偏析がしばしば観測される。この電子ドナー 元素の表面偏析現象が、（母相金属表面が本来有する）腐食 反応を担う化学種を活性にする解離触媒効果を抑える場合 があり、これを利用した材料開発が行われメタルダスティ ング耐食合金材料として実用化されている ${ }^{9}$ 。金属組織だ けでなく結晶構造までをも、ある意味で“野篦坊”にして しまったような Friedel モデルが、実用材料の開発コンセプ トの創出にも活用できるという一例である。

\section{3. 結晶格子の弾性物性と相安定性}

本節では、微小歪に対する応答現象である弾性物性と熱 力学的な相安定性の相関を概観しておく。

原子間結合が強い系では、周囲からの歪摂動に対して、 基底状態からの全エネルギーが急峻に増加するため、微小 歪に対する抵抗指標となる弾性定数は一般的に大きくなり そうである。また、一次相転移は一般的に着目相の原子間 結合を大なり小なり変化させるものであるから、当該相の 相安定性も原子間結合の強さに依存しそうではある。した がって、結晶における弾性物性と相安定性に何かしらの相 関が現れそうなことは直感的にも想像される。

実測值からこの種の相関を整理しようという試みは多く あり、例えば、Fine 等は多くの立方晶金属系において融点 $T_{M}$ と弾性定数 $C_{11}$ に対して線形関係が見られることを指摘 している ${ }^{10)}$ 。単位格子の小さい系の弾性定数は、現在では 第一原理計算でも簡便に評価できるので、遷移金属系の fcc 


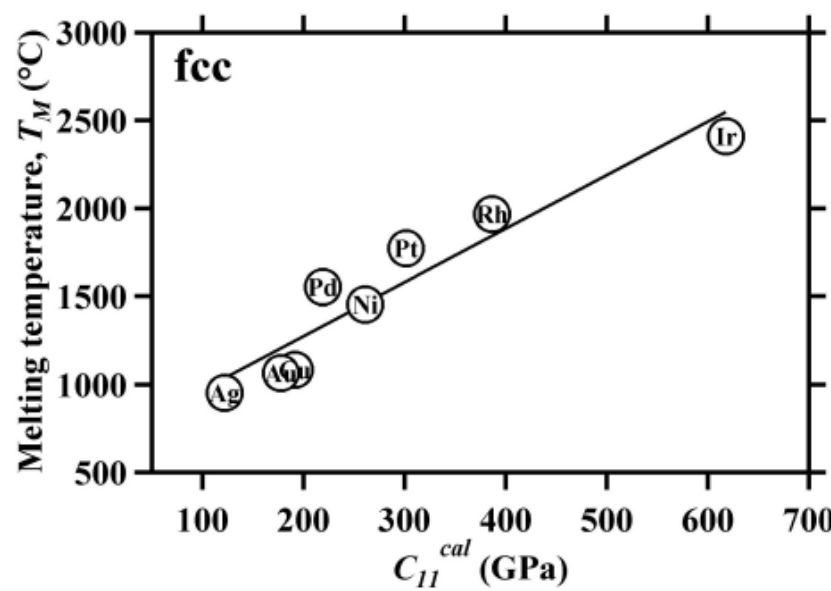

Fig. 3 Thermodynamic melting points $\left(T_{M}\right)$ as a function of $C_{I I}{ }^{c a l}$ for fcc transition metals. The $C_{I l}{ }^{c a l}$ are evaluated using the firstprinciples calculations.

格子の計算結果を利用した弾性定数 $C_{l l}$ と融点 $T_{M}$ との関係 をFig. 3 に示す。Fine 等が指摘するように両者には比較的 良好な線形相関が見られるのが分かる。

Fig. 4(a)には、4d 遷移金属系における fcc 及び bcc 構造 の格子エネルギーの第一原理計算值を示した (hcp 構造をエ ネルギー基準にして表示)。遷移金属系では、周期律表の左 側から基底状態の結晶構造が hcp $\rightarrow \mathrm{bcc} \rightarrow \mathrm{hcp} \rightarrow \mathrm{fcc} \rightarrow \mathrm{hcp}$ と推移する（磁性による $3 \mathrm{~d}$ 遷移金属系の例外はある）。第 一原理計算による全エネルギーの解析からも、この結晶構 造安定性の周期律表推移が再現されることが分かる。遷移 金属系に扔ける安定な結晶構造がこの順で周期律表を推移 するのは、電子状態密度 (DOS) の具体的な形が結晶格子で 決定されるため、前節に述べた結合・反結合状態境界のバ ンド底からの相対位置が、結晶構造に依存することで生ず る格子間競合安定性に由来することが、Andersen 等のカノ ニカルバンド解析（原子核の個性を排除したバンド理論解 析）から分かっている ${ }^{11}$ 。遷移金属系では、結晶構造の安 定性（相安定性）についても、 $\mathrm{d}$ 電子数 $\left(n_{d}\right)$ が本質的な役 割を担うのである。

Fig. 4(b) には、fcc 及び bcc 格子の 剛性率 $C^{\prime}\left(=\left(C_{I I}-\right.\right.$ $C_{12} / 2$ ) の計算結果を揭げた。本図における剛性率の負值は、 当該歪による断熱ポテンシャル曲線が上に凸となる弾性不 安定性（elastic instability あるいは Born instability）と呼ば れる格子力学不安定性が出現することを物理的には意味す る。bcc 格子の相安定領域では fcc 格子（最密格子）の弾性 不安定性が出現し、逆にfcc（最密格子）の相安定領域では bcc の弾性不安定性が出現することが分かるだろう。ここ で述べた bcc と fcc（最密格子）間の弾性不安定性の相反性 は、種々の理論解析からかなり普遍性の高いものであるこ とが指摘されており ${ }^{12} 13$ )、また次節で後述するように Bain

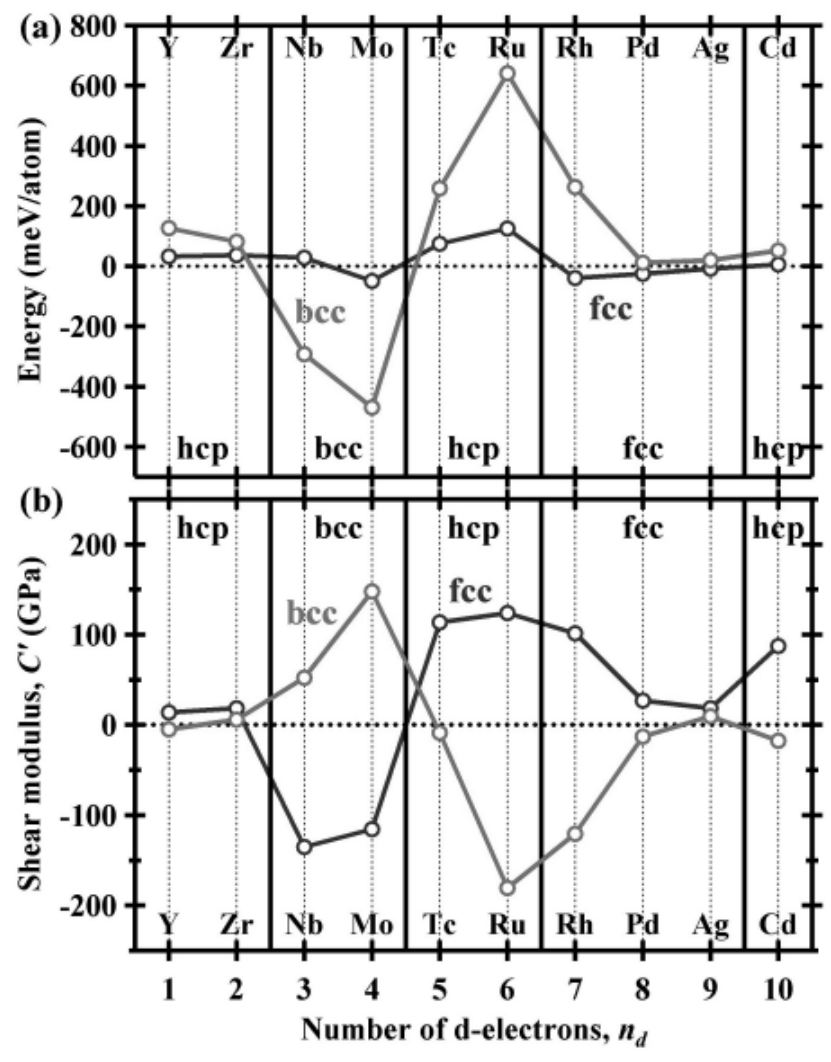

Fig. 4 (a) Lattice energy increments from hep structure and (b) shear moduli of $C^{\prime}\left(=\left(C_{11}-C_{12}\right) / 2\right)$ calculated for fcc and bec in the $4 \mathrm{~d}$ transition metals.

変形に関するエネルギー曲線からも幾何学的に理解するこ とができる。このように、結晶の相安定性は剛性率のよう な弾性物性とも密接に関わっており、逆に弾性物性を詳細 に考察することは相安定性の本質的な理解にもつながる可 能性がある訳である。

結晶格子間の相安定性と剛性率の相関を前述したが、融 解現象のような着目固体相の高温側の相安定性も剛性率が 密接に関わってくる。液相は流動性を有するため、“剛性率 が消滅した相”と定義しても良さそうなので、こちらの方 が上述の結晶安定性と弾性物性の相関よりも直感的に理解 しやすいかもしれない。Fig. 5 に、Al 系の EAM ポテンシャ ル (Embedded Atom Method) を利用した圧力一定 (NPT) アン サンブルの分子動力学法による昇温過程の固液相転移の様 子を示す ${ }^{4)}$ 。実際の融解現象は、表面あるいは久陥を基点 とする典型的な不均一核形成をきっかけとする相転移であ るため、久陥を含まない完全結晶の分子動力学法では、熱 力学融点 (Thermodynamic melting point: $T_{M}^{t}$ ) で融解現象を起 こさず、かなりの過熱状態 (super-heating) が通常観測され る。ある温度で原子体積や㴊性率に不連続性が観測される が、この温度を機械的融点 (Mechanical melting point: $T_{M}{ }^{m}$ ) と 呼び、これが固体の過熱状態の限界温度となる。緒言に述 


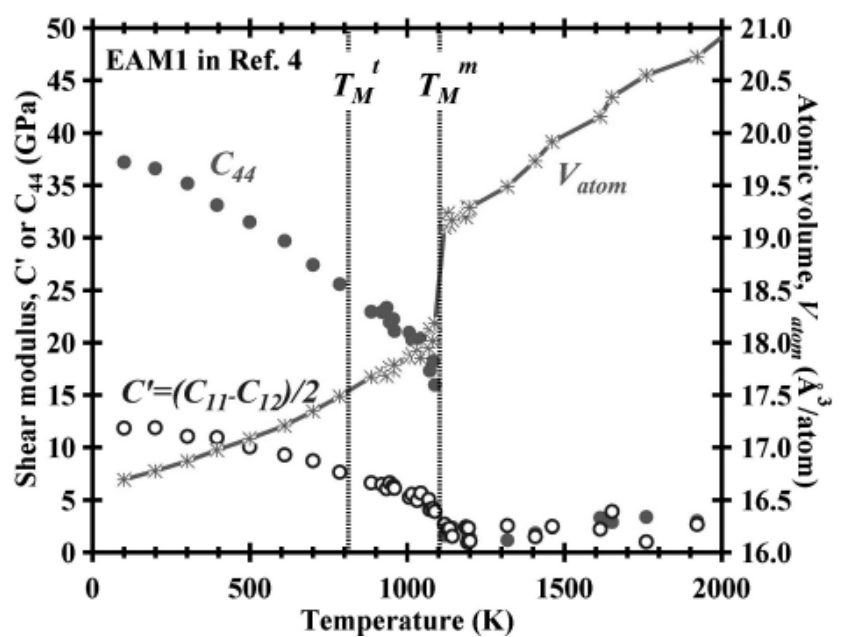

Fig. 5 Typical example of the temperature dependence of the atomic volume $\left(V_{\text {atom }}\right)$ and shear moduli $\left(C^{\prime}\right.$ and $\left.C_{44}\right)$ based on the molecular-dynamics simulations ${ }^{4} . T_{M}{ }^{t}$ and $T_{M}{ }^{m}$ denote the equilibrium (thermodynamic) and mechanical melting points, respectively.

ベた Lindemann criterion ${ }^{1)}$ あるいは Born criterion ${ }^{2)} に$ 関して は、Lennard-Jones ポテンシャルを利用した精密な分子動力 学解析から、熱力学融点 $\left(T_{M}{ }^{t}\right)$ ではなく機械的融点 $\left(T_{M}{ }^{m}\right) に$ おいて同時に満たされる転移基準であることがJin等によっ て指摘されている ${ }^{14)}$ 。いくつかの $\mathrm{Al}$ 系の $\mathrm{EAM}$ ポテンシャ ルを利用した著者達の分子動力学解析では、 $T_{M}{ }^{t}$ と $T_{M}{ }^{m}$ 間に は、かなりの精度での線形性が観測されている4)。しがっ て、温度上昇に伴う剛性率低下の振る舞いが物質間でそれ ほど異ならないならば、結晶の高温側の相安定性について も、剛性率の大きさと良い相関がある程度見出されそうな ことが示唆される。

\section{Bain 変形のエネルギー曲線：相反格子間の相安定性と 弾性不安定性}

本節では、様々な金属材料に重要な fcc-bcc 間の相安定 性が、相反格子の弾性不安定性という格子力学不安定性に 密接に関与することを、Bain 変形のエネルギー論から概説 する。

固体の高温相安定性に関しては、材料学的側面から興味 深い知見がいくつかの第一原理計算解析から指摘されてい $3^{15), 16)}$ 。Willis 等は、局所密度近似 (LDA) の枠組みの第一 原理計算から、立方晶遷移金属系の Bain 変形の energetics と剛性率 $\left(C^{\prime}\left(=\left(C_{11}-C_{12}\right) / 2\right)\right)$ の相関を解析し、例えば基 底状態が $\mathrm{fcc}$ 格子の場合 $\Delta E=E_{b c c}-E_{f c c}(E$ は全エネルギー) が大きいほど、剛性率 $C$ 'が大きそうだと指摘した ${ }^{15)}$ 。こ の様子は、前節の Fig. 4 の計算結果にも表れているのが分 かる。同様な考察は、米国海軍研究所の Mehl 等によって もされており、彼等は上述した Born criterionの絡みから、

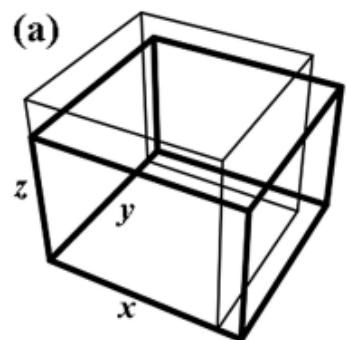

(b)

Fig. 6 Schematic illustrations of (a) the lattice deformation under Bain strain and (b) the body centered tetragonal (bct) crystal structure inside fcc one.

$\Delta \mathrm{E}$ が融点と相関がありそうなことも指摘している ${ }^{16)}$ 。

ところで、Bain 変形とは、鋼のマルテンサイト変態のモ デルとして 1924 年にBain が提案 ${ }^{17)}$ した Fig. 6(a)に示すよ うな立方晶の tetragonal な歪変形である。弾性論が適用でき る微小歪下では、立方晶の歪エネルギーは、

$$
\begin{aligned}
E_{s t r}= & \frac{1}{2} C_{11}\left(e_{11}{ }^{2}+e_{22}{ }^{2}+e_{33}{ }^{2}\right) \\
& +C_{12}\left(e_{11} e_{22}+e_{22} e_{33}+e_{33} e_{11}\right) \\
& +\frac{1}{2} C_{44}\left(e_{12}{ }^{2}+e_{23}{ }^{2}+e_{13}{ }^{2}\right)
\end{aligned}
$$

と書けるので ${ }^{0} 、 F i g .6(a)$ の歪に相当する、

$$
e_{11}=-e_{33}=\frac{1}{2} e, \text { other } e_{i j}=0
$$

を式(3)に代入すれば、

$$
E_{s t r}=\frac{1}{2} C^{\prime} e^{2},\left(\because C^{\prime}=\frac{C_{11}-C_{12}}{2}\right)
$$

となり、Bain 変形パス (Bain path)における微小歪領域の工 ネルギーポテンシャル曲線の曲率が剛性率 $C$ 'を与えるこ とが導かれる。

さて、Bain パスの変形歪をもっとずっと大きくしていく と何がおきるだろうか。Fig. 6(b) に、fcc 結晶格子の原子 模型を示した。fcc 格子は、少し別の見方をすると薄色原子 で示すような bct 格子で形成されている様子が分かる。こ の格子に Fig. 6(a) のような変形を施すと、ある歪量（変形 量）で、内在する bct 格子が bcc 格子に一致することがイ メージできるだろう。これが、Bainが最初にイメージした 鋼のマルテンサイト変態過程の反応パスである ${ }^{17)}$ 。Bain パ スは現実の $\mathrm{fcc}-\mathrm{bcc}$ 相転移パスを必ずしも表現するもので ないことが今日では分かっているが、エネルギー論的なト レンド把握の利便性や概念構築場面での理論的有用性のた め、現在でも様々な理論研究に利用されている重要コンセ プトとなっている ${ }^{13)}$ 。実際の鋼のマルテンサイト変態では、 


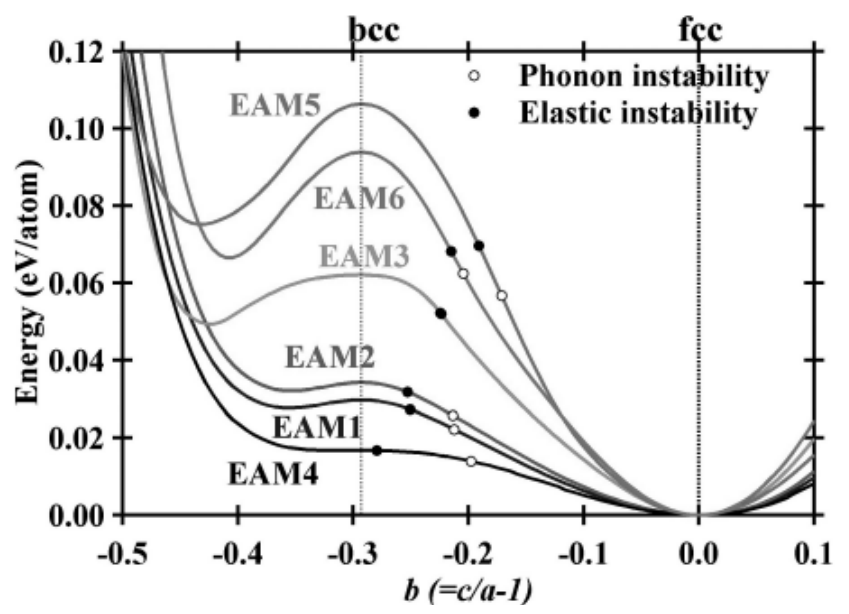

Fig. 7 Typical examples of energy curves along the Bain path calculated using some EAM models of $\mathrm{Al}^{4}$. We also show the location of instabilities for each potential model in the energy curve along the Bain path.

母相（fcc 相）との間でいくつかの結晶方位関係（orientation relationship）が観測され ${ }^{18)} 、$ かり複雑な変態パスを通る ようだが、この辺りの前線研究については森戸氏が本特集 号で解説されるだろう。

$\mathrm{fcc}$ 格子が基底状態となるいくつかの $\mathrm{Al}$ 系 $\mathrm{EAM}$ ポテン シャルを利用した、典型的な Bain パスのエネルギー曲線を Fig. 7 に示す ${ }^{4)}$ 。横軸は、底面 (xy 面) の格子定数 $(a)$ と 変形歪 (Fig. 6) で変化する $z$ 軸方向の格子定数 $(c)$ を利用し て算出される歪量 $b(=c / a-1)$ である。 $b=0$ が fcc 格子に、 $b=1 / \sqrt{2}-1$ が bcc 格子に相当することになる。 Bain パスの エネルギー曲線は、fcc (bcc) 格子が基底状態の場合、 bcc (fcc) 格子で極大值を示す。上述したように基底状態（Fig. 7 で は fcc 格子 : $b=0$ ）近傍の曲率が厳密に剛性率 $C$ 'を与える ため、この曲率が大きいほど相反格子 (Fig. 7 では bcc 格子 : $b=1 / \sqrt{2}-1)$ の極大值は大きくなりそうで、先の Willis 等 の指摘 ${ }^{15)}$ は非常にもっともらしいことが、Fig. 7 のエネル ギー曲線からも見て取れる。また、bcc 格子近傍のエネル ギー曲線は上に凸の曲線になっており、相反格子において なぜ剛性率 $C$ 'が負值を取り（Fig. 4(b)）弾性不安定性が発 現するのかも、このエネルギー曲線から幾何学的に理解で きるだろう。これは bcc-fcc 間の相対的な結晶安定性が、 相反格子の弾性不安定性に本質的に由来することを示唆し ている。本節で示した相反格子間の熱力学的安定性と弾性 不安定性の関係は、多くの bcc-fcc（より一般的には最密 格子）金属系で成立する普遍性の高い相関であることが、 ごく最近 Grimvall 等により米国物理学会誌に総合報告され ていることを付け加えておきたい ${ }^{13)}$

\section{5. 格子力学不安定性と相転移温度}

前節では、Bain 変形のエネルギー曲線から、 bcc-fccの

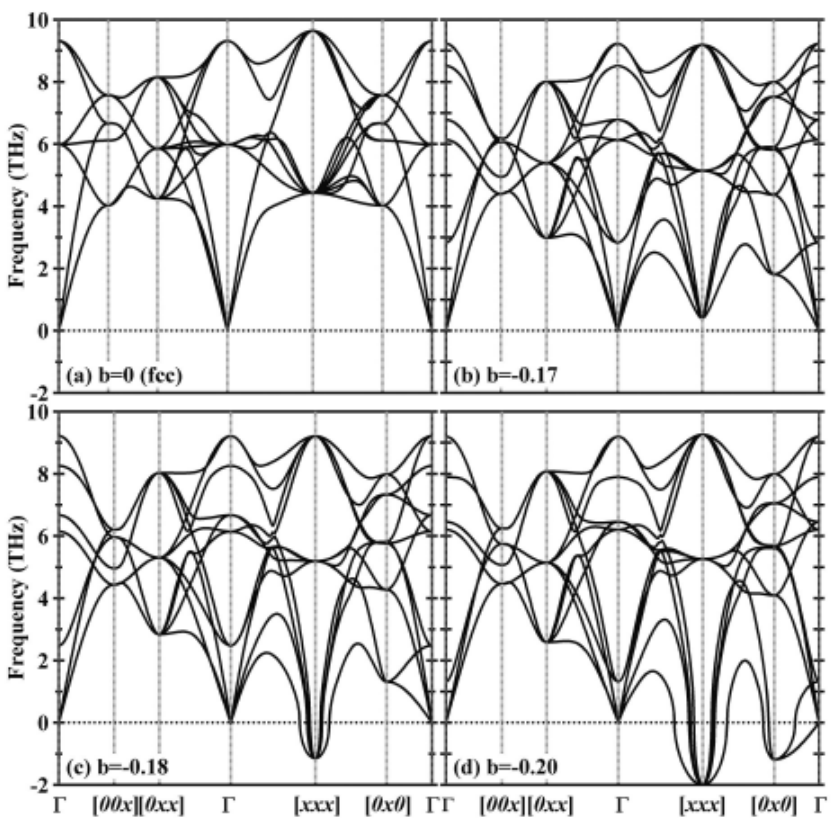

Fig. 8 Phonon dispersion curves ${ }^{4)}$ as a function of strain parameter, $b$, along the Bain path (see also Fig. 7) for an EAM-Al model ${ }^{19)}$. These calculations are carried out using the conventional cell of the face-centered tetragonal (fct) structure. The negative values are used to plot imaginary frequencies for convenience. $x$ denotes the value of $1 / 2$ in units of reciprocal unit vectors.

ような相反格子間の熱力学的安定性と弾性不安定性の関係 を述べた。本節では、もう少し一般的に格子力学不安定性 と相転移温度の関係を概説する。

結晶固体を Bain 変形のように大きく歪ませると、通常、 その結晶には当該歪エネルギー曲線には顕に見えなかった 別のモードのフォノン不安定性 (phonon instability) や弾性不 安定性 (elastic instability) といった格子力学不安定性が出現 してしまう場合がある。Mishin 等の提出した EAM モデル 19)を利用して解析した、Bain 変形下における fcc-Al 系での 格子力学不安定性の例を Fig. 8 に示す ${ }^{4)}$ 。外部からある程 度の歪摂動を受けると、当該結晶には Brillouin ゾーン内の [1/2 1/2 1/2] 点でソフトモードが観測され (Fig. 8(b))、さら に大きな歪摂動を受けると、まず、ゾーン中心（「 点）か ら遠い所で周波数が複素数になるフォノン不安定性(phonon instability) が誘起される (Fig. 8(c))。歪量 $b$ がさらに増加 すると、今度は Brillouin ゾーン中心（ $\Gamma$ 点）近傍でも、周 波数が複素数になる弾性不安定性 (elastic instability) が顕在 化する（Fig. 8(d)）。結晶格子は、実はそれほど大きな歪 には耐えられず、自発的な変形がこの格子力学不安定性に よって誘起される可能性がある訳である。

Fig. 7 内に示した点（○及び○）は、いくつかの EAM$\mathrm{Al}$ モデルに対して、Bain 変形下でフォノン不安定性や弾性 不安定性が発生するポテンシャル空間での位置である。こ のエネルギー位置と熱力学融点には強い線形性がありそう 


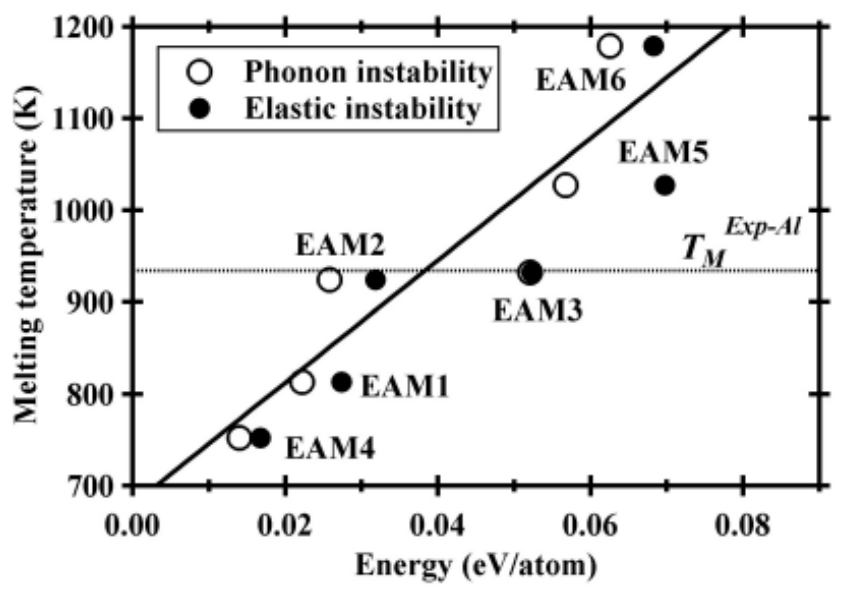

Fig. 9 Relation between the thermodynamic melting temperatures and the energy locations of phonon ( $\bigcirc$ ) and/or elastic instabilities $(\mathbf{O})^{4}$.

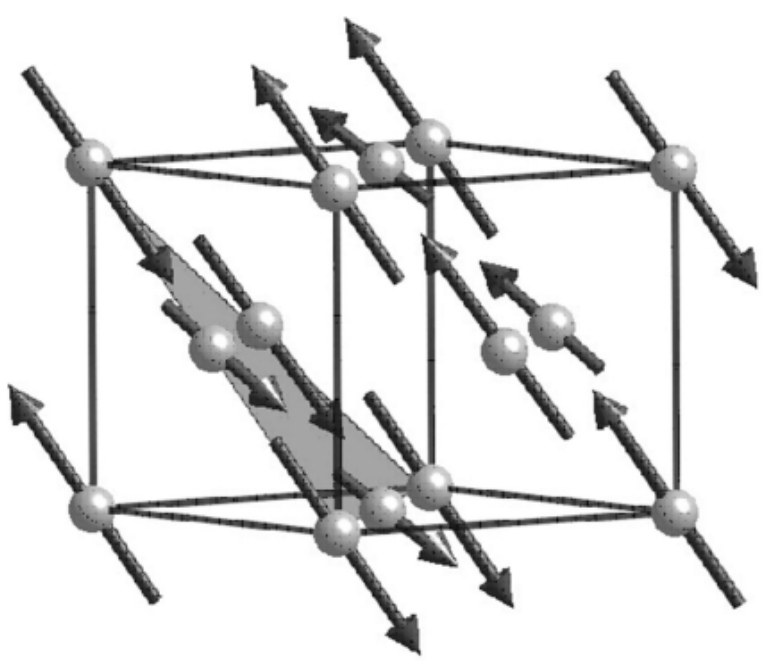

Fig. 10 Schematic of the phonon instabilities first appeared under strain along the Bain path ${ }^{4}$. The unstable mode corresponds to the displacements in approximately the $<112>\{111\}$ directions.

なことが、我々の解析からは見出されている (Fig. 9)。固 液相転移には、固体の energetics だけでなく格子力学的な instability が重要なステップ要素であることを示唆する結果 である。

より興味深いのは、この変形下で現れる最初のフォノン 不安定性が、fcc 結晶に扔ける Heidenreich-Shockley の部分 転位や双晶方位のバリアントとして知られる $<112>\{111\}$ 方 位となることである（Fig. 10）。つまり、ある歪下で、原子 群は障壁を感じずにこの方位に対して自発変位が可能とな る。これは、fcc 結晶の融解現象は、結晶内の転位 (dislocation) の発生のしやすさに関与することを示唆している。

これを、定量的に議論するために、一般化積層欠陥エネ

\section{(a) EAM5}
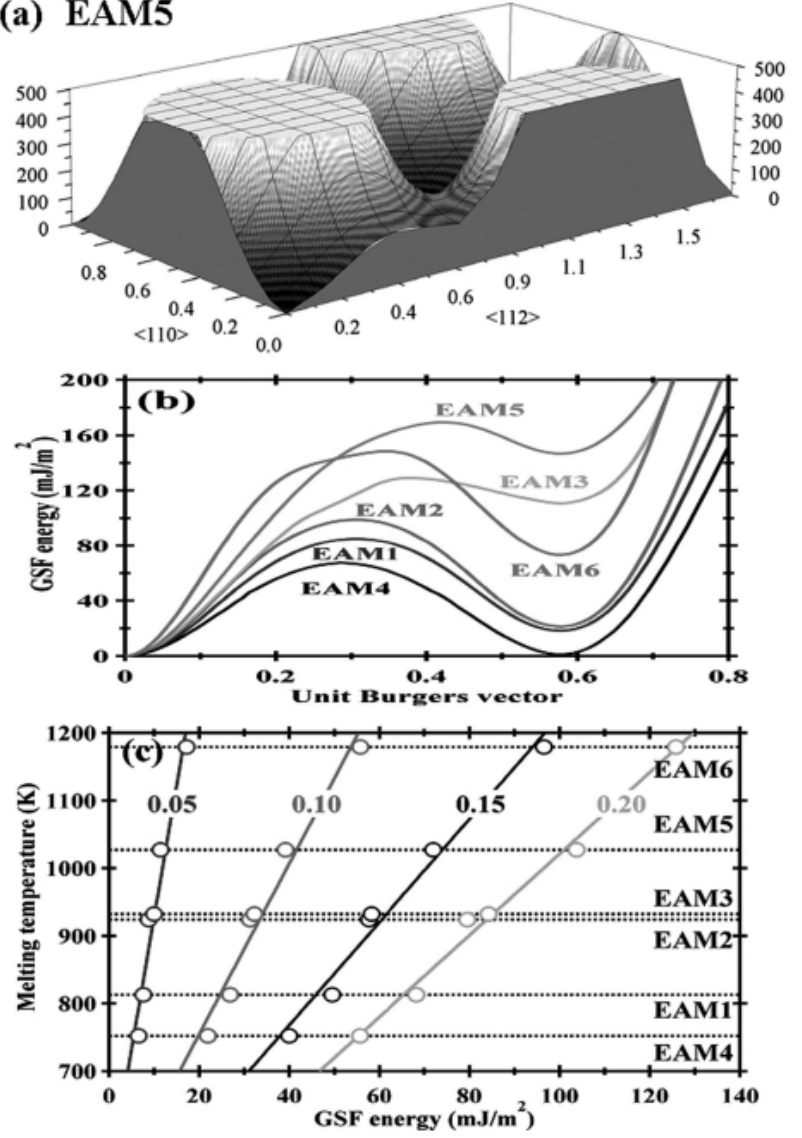

Fig. 11 (a) Example of $\gamma$ surface for displacements along a (111) plane in fcc-Al with the equilibrium lattice constant $\left(a_{0}\right)$. The energy and displacement units are in $\mathrm{mJ} / \mathrm{m}^{2}$ and in the unit Burgers vector, $|\boldsymbol{b}|=\left|a_{0}[101] / 2\right|$, respectively. The energy surfaces exceeding the value of $500 \mathrm{~mJ} / \mathrm{m}^{2}$ are truncated. The corners of the plane and its center correspond to identical equilibrium configurations, i.e., the ideal fcc lattice. (b) Projections of the $\gamma$ surfaces on the $<112>$ direction calculated using some EAM-Al potentials. (c) Relation between the thermodynamic melting temperatures and the GSF energies along the $<112>$ direction, where the internal figures of $0.05,0.10,0.15$ and 0.20 show the displacement values expressed by the unit Burgers vector. All these figures are reproduced from the original data in Ref. [4].

ルギー (Generalized Stacking Fault Energy (GSFE) or $\gamma$ surface) と融点との相関を解析した結果を ${ }^{4)}$ 、本節の最後に言及し ておこう。 $\gamma$ surface とは着目したすべり面に隣接する平行 原子面間の相対的な“ずれ”によって生じるエネルギーポ テンシャル曲面で、Vitekによってその基礎概念が導入され た (Fig 11(a) $)^{200}$ 。 Al 系 EAM ポテンシャルを利用した (111) 面 $\gamma$ surface の $<112>$ 方向へのエネルギー断面曲線を Fig. 11(b)に示す。この曲線に打ける最初のエネルギー極大值 は、unstable stacking fault energy と呼ばれ、結晶内の転位 生成の抵抗指標となる重要な材料物性值であることが Rice によって指摘されている ${ }^{21)}$ 。次に現れるエネルギー極小值 が、通常の積層欠陥エネルギー (stable stacking fault energy) 
となる。Fig. 11(c) は、 $\gamma$ surface の $<112>$ 方位曲線の立ち 上がり部分に、熱力学融点との強い線形相関が定量的に見 出されることを示したものである ${ }^{4)}$ 。固液相転移では、か なり旧くから結晶内の転位発生が、固体の融解現象に重要 な因子ではないかという思想があった (Dislocation-mediated melting $)^{22)}$ 。本節に概説した解析結果は ${ }^{4)}$ 、融解現象が、固 体相側から見ると、やはり転位誘起型の一次相転移 ${ }^{22)}$ であ る可能性が高いことを示唆していると考えられる。

\section{6. 鉄の Bain パスエネルギー：磁性の影響}

4 節では、Bain 変形のエネルギー曲線から、 bcc-fcc の ような相反格子の存在、これらの熱力学的安定性と弾性不 安定性の関係を述べた。しかしながら、鋼のような鉄基合 金では、マルテンサイト変態 $(\mathrm{fcc} \rightarrow \mathrm{bct}$ ) や $\gamma \rightarrow a$ 変態 $(\mathrm{fcc} \rightarrow \mathrm{bcc})$ が実際に存在する。この疑問に答えるため、本 稿の最終節では、鉄 $(\mathrm{Fe})$ の Bain パスエネルギーが磁性（ス ピン分極）の存在で、どんな変化を受けるかを概説する。

鉄や鉄基合金は、最も歴史の永い構造材料であり、産業 上も重要な地位を占める金属材料であるが、ミクロな物理 的観点からは、相安定性や格子力学安定性に対して未解明 な部分が多い物質系でもある。これは、主に、Fe 元素の 固体相におけるスピン構造の複雑さに由来している。特に やっかいなのが fcc 格子近傍の安定性で、その原子体積に 依存して、非磁性 (non-magnetic: NM)、強磁性 (ferromagnetic: FM)、反強磁性 (anti ferromagnetic: AF) やスピンスパイラル (spin-spiral: SS) のような不整合磁性状態 (non-collinear: NC) が、数 $\mathrm{mRy} /$ atom $(1 \mathrm{Ry}=13.6 \mathrm{eV})$ 程度のエネルギー差で混 在する物質系であることが知られている ${ }^{23)}$ 。

ただし、強磁性 (FM) 及び非磁性状態 (NM) における bcc - fcc の格子力学的な相反性（4 節参照）については、密度 汎関数法 (Density Functional Theory: DFT) の枠組みでのフォ ノン分散曲線の解析から確かめられている ${ }^{2425)}$ 。Hsueh 等は、 bcc-Feに対して、磁気モーメントを固定した第一原理計 算 (fixed-spin-moment calculations) を行い、磁気モーメント が $\mu=2.2$ 程度の FM 状態では格子力学安定性を有するが、 $\mathrm{NM}$ 状態に近い所では弾性不安定性（ $\Gamma$ 点近傍に複素周波 数）が現れることを報告している ${ }^{24)}$ 。一方、 $\mathrm{fcc}-\mathrm{Fe}$ に対し ては、Zhang が同様な理論解析から、bcc 格子とは相反する ように NM 状態近傍では格子力学安定性を有するが、 $\mu=2.0$ 程度の FM 状態では弾性不安定性（ $\Gamma$ 点近傍に複素周波数） が現れることを指摘している ${ }^{25)}$ 。

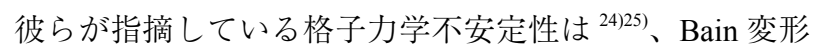
のエネルギー曲線を固定磁気モーメント計算で導出するこ とにより、幾何学的に理解することができる。その様子を、 Fig. 12 に示す。この図は、磁気モーメントを非磁性状態 $(\mu$ $=0)$ から強磁性状態 $(\mu=2.0$ 程度）まで変化させた時の、 Bain 変形のエネルギー曲線を示したものである。ただし、 原子体積は非磁性状態の fcc 格子の平衡体積に固定してい

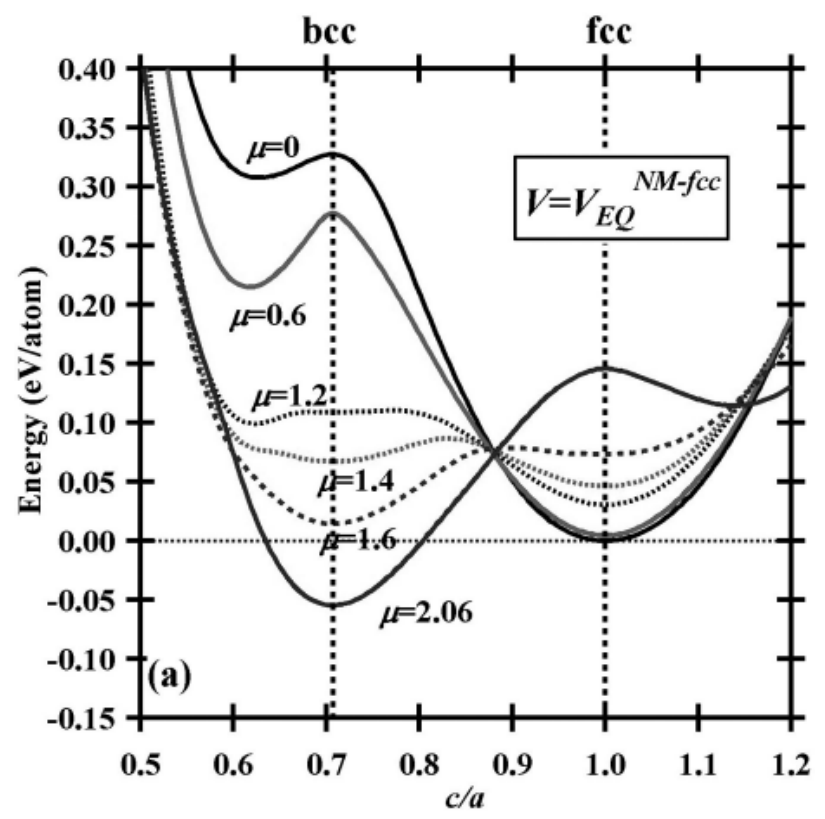

Fig. 12 Bain path energetic curves as a function of spin moment $(\mu)$ for iron, which have been evaluated using the fixed-spinmoment calculation technique within the generalized gradient approximation (GGA)

る。また、エネルギーの原点も、非磁性状態の fcc 格子の エネルギーにとっている。磁気モーメントの増大につれて、 $\mathrm{fcc}$ 格子がエネルギー的に不安定になり、bcc 格子のエネル ギー的安定性が顕在化する様子が見て取れる。また、磁気 モーメントの小さい所では、bcc 格子近傍のエネルギー曲 線が上に凸となる弾性不安定性 (Born instability) が現れ、逆 に磁気モーメントの大きい所では fcc 格子近傍に弾性不安 定性が現れることが分かるだろう。このように、鉄あるい は鉄基合金では、 bcc-fcc 格子間の熱力学的安定性や弾性 不安定性に関しては、磁性相互作用が本質的役割を担う。

ところで、鋼の相変態温度に対する元素組成の依存性に ついては、研究の歴史も永く様々な経験式が提出されてい る。例えば、マルテンサイト変態開始温度に関するものと しては、下記のようなものがよく知られる ${ }^{26)}$

$\mathrm{Ms}(\mathrm{K}$, at: \%) $=818-71 \mathrm{C}+\mathrm{Al}+7 \mathrm{Co}-14 \mathrm{Cr}-15 \mathrm{Cu}$

$-23 \mathrm{Mn}-8 \mathrm{Mo}-6 \mathrm{Nb}-13 \mathrm{Ni}-4 \mathrm{Si}+3 \mathrm{Ti}-4 \mathrm{~V}+0 \mathrm{~W}$

上式は、熱力学的にはオーステナイト相（fcc 相）の低温 側の相安定性を示す指標となるものであるが、変態温度に 対する元素の重み係数や土符号についての原子レベルの物 理的な意味や機構についてはほとんど分かっていない。本 節で述べたように、鉄基合金では、高温で格子力学安定性 を有する fcc 状態が、低温化に伴う磁気相互作用によって bcc 状態の格子力学不安定性が消滅し、ある温度で相変態 に至るものであろうことが定性的には予想される。しかし 
ながら、これまでこのような格子歪エネルギー論の観点か ら、鋼のマルテンサイト変態過程の実験的考察を行おうと する研究の試みは少なかったように思われる。

4 節で述べたように、Bain 変形のエネルギー曲線には、 定量的に剛性率の振る舞いがのる。したがって、相反格子 となる bcc 状態の隠れた格子力学不安定性の消滅過程の観 測は困難かもしれないが、変態過程の fcc 格子の剛性率の元 素依存性がその場測定できれば ${ }^{27)}$ 、オーステナイト相 ( $\gamma$ 相) の相安定性の指標となる変態前の当該エネルギー曲線の一 端は垣間見ることができるかもしれない。本稿に関連した トピックス研究であるマルテンサイト変態過程の弾性物性 その場測定に関する論文では、炭素原子による Bain 変形の エネルギー曲線の曲率変化が、オーステナイト相の低温側 の安定性に重要な素過程となっていそうな旨が示される。

\section{7. おわりに}

本稿では、結晶固体が持つ弾性のような力学物性が、熱 力学相安定性に関する物性と、ミク口的観点からどのよう につながるのかを、著者達の理論研究もべースに概説した。 2 節では、遷移金属系の凝集物性の周期律表のトレンドを 概観するのに有用な Friedel モデルを紹介し、金属組織だけ でなく結晶構造までをも、ある意味で“野篦坊”にしてし まった本モデルが、実用材料の開発コンセプトの創出にも 活用できる場面があることを述べた。3 節で、結晶格子の 弾性物性と相安定性の相関を概観した後、4節では、比較 的新しい概念である bcc-fcc 格子間に存在する弾性不安定 性の相反性について記述した。この辺りは、仮想格子にお けるフォノン・弾性不安定性に関する正確な原子レベル計 算が可能になった 1990 年以降の理論知見の貢献が大きい。 5 節では、4 節の話題を拡張し、固液相転移温度がフォノ ン不安定性とどのようにつながるかを詳述した。著者達の 計算解析から得られた $\gamma$ surface と融点の関係にも言及し、 結晶材料の相変態現象が、転位 (dislocation) の発生という 概念にも絡む場面がありそうな旨を述べた。6節では、鉄 $(\mathrm{Fe})$ の Bain パスエネルギーが磁性（スピン分極）の存在でどん な変化を受けるかを概説し、鉄あるいは鉄基合金では bcc - fcc 格子間の熱力学的安定性や弾性不安定性に関しては、 磁性相互作用が本質的役割を担うことを述べた。

結晶固体の相変態現象は、当該結晶の格子力学不安定性 (結晶が力学的に不安定となりその構造を保てなくなる現 象）に関与することが多いと思われるが、電子論的複雑性 を有する鉄鋼材料を、このような観点から考察する実験研 究はまだ途についたばかりと思われる。添加元素の削減、 省略や代替を図る指導原理の解明や元素機能の更なる発揮 は、今後の鉄鋼材料開発における最重要課題でもある。先 端的な実験科学と計算科学の融合によって、今後も元素機 能の基礎的解明がますます進展することを期待しつつ本稿 を終わりたい。

\section{謝 辞}

Fig. 3 及び Fig. 4 の計算解析は、佐藤悠氏（当時：大阪 大学工学部三回生）が、住友金属工業（現：新日鐵住金） における 2011 年度夏季インターンシップの実習中に行った ものです。本稿執筆にあたり、同氏に感謝の意を表します。

\section{引用文献}

1) F. Lindemann, Z. Phys, 11 (1910), 609-612.

2) M. Born, J. Chem. Phys. 7 (1939), 591-603.

3) W. Ostwald, Z. Phys. Chem. 22 (1897), 289-330.

4) K. Moriguchi and M. Igarashi, Phys. Rev B 74 (2006), 024111.

5) J. Friedel, “The Physics of Metals I, Electrons", ed. by J. M. Ziman, Cambridge University Press, 1969.

6) C. Kittel、“キッテル固体物理学入門第 8 版”、丸善、(2005).

7) 山下次郎、固体電子論、朝倉書店、(1973).

8) A. V. Ruban, H. L. Skriver and J. K. Nørskov, Phys. Rev. B 59 (1999) 15990-16000.

9）西山佳孝、森口晃治、岡田浩一、小薄孝裕、栗原伸之佑、ま てりあ 52 (2013)23-25.

10) M. E. Fine, L. D. Brown and H. L. Marcus, Scr. Metall. 18 (1984), 951-956.

11) O. K. Andersen and J. Madsen and U. K. Poulsen and O. Jepsen and J. Kollár, Physica B+C 86-88 (1977), 249-256.

12) M. J. Mehl, A. Aguayo, L. L. Boyer and R. de Coss, Phys. Rev. B 70 (2004), 014105.

13) G. Grimvall, B. Magyari-Köpe,V. Ozoliṇ̌s, K.Persson, Rev. Mod. Phys. 84 (2012), 945-986.

14) Z. H. Jin, P. Gumbsch, K. Lu and E. Ma, Phys. Rev. Lett. 87 (2001), 055703.

15) J. M. Wills, O. Eriksson, P. Soderlind and A. M. Boring, Phys.Rev. Lett. 68 (1992), 2802-2805.

16) M. J. Mehl and L. L. Boyer, Phys. Rev. B 43 (1991), 9498-9502.

17) E. C. Bain, Trans. Am. Inst. Min., Metall. Pet. Eng. 70 (1924), 2535 .

18) S. Morito, H. Tanaka, R. Konishi, T. Furuhara, T. Maki, Acta Materialia 51 (2003), 1789-1799.

19) Y. Mishin, D. Farkas, M. J. Mehl and D. A. Papaconstantopoulos, Phys. Rev. B 59 (1998), 3393-3407.

20) V. Vitek, Cryst. Lattice Defects 5 (1974), 1-34.

21) J. R. Rice, J. Mech. Phys. Solids 40 (1992), 239-271.

22) J. G. Dash, Rev. Mod. Phys. 71 (1999), 1737-1743.

23) L. Tsetseris, Phys. Rev. B 72 (2005), 012411.

24) H. C. Hsueh, J. Crain, G. Y. Guo, H. Y. Chen, C. C. Lee, K. P. Chang and H. L. Shih, Phys. Rev. B 66 (2002), 052420.

25) W. Zhang, Journal of Magnetism and Magnetic Materials 323 (2011), 2206-2209.

26) M. Palumbo, Calphad 32 (2008),693-708.

27) H. Terasaki, H. Yamagishi, K. Moriguchi, Y. Tomio and Y. Komizo, J. Appl. Phys. 111 (2012), 093523; ibid (2012), 079901. 